\title{
Degradation Reactive Black 5 dye from aqueous solutions using ozonation with pumices and pumices modified by nanoscale zero valent iron (nZVI)
}

\author{
Rahmani A. ${ }^{1}$, Rahmani H. ${ }^{2,3}$ and Rahmani K. ${ }^{4}$ \\ ${ }^{1}$ Department of Environmental Health Engineering, School of Health, Semnan University of Medical Sciences, Semnan, Iran \\ 2Department of Environmental Health Engineering, School of Health, Kashan University of Medical Sciences, Kashan, Iran \\ ${ }^{3}$ Research Center for Social Determinants of Health (SDOH), Kashan University of Medical Sciences, Kashan, Iran \\ ${ }^{4}$ Department of Environmental Health Engineering, Mamasani Higher Eduction Complex for Health, Shiraz University of Medical \\ Sciences, Shiraz, Iran \\ Received: 05/09/2017, Accepted: 23/08/2020, Available online: 31/08/2020 \\ *to whom all correspondence should be addressed: e-mail: krahmanii@yahoo.com \\ https://doi.org/10.30955/gnj.002453
}

\section{Graphical abstract}

Removal efficiency of COD and RB5 by ozonation with raw pumice and pumice-nZVI

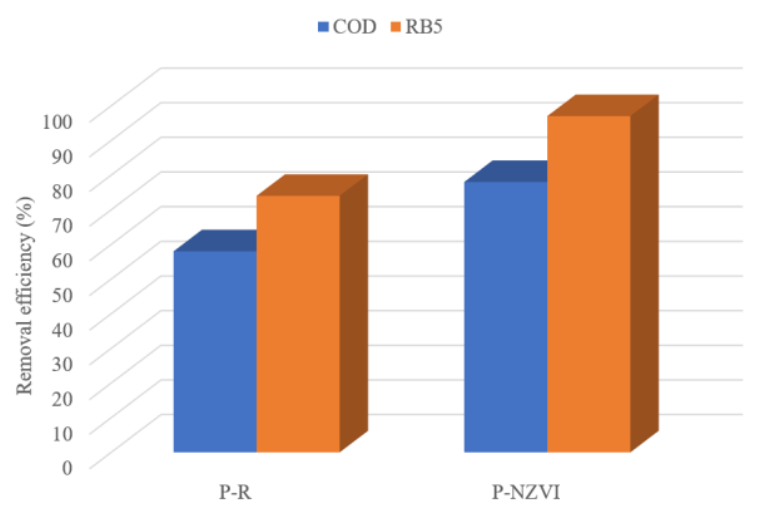

\section{Abstract}

Reactive Black 5 (RB5) dyes are a dye widely used in textile industries. The nanocatalytic ozonation of RB5 solution in the presence of pumice modified with nanoscale zero valent iron ( $\mathrm{nZVI}$ ) catalysts and pumice raw investigated in a laboratory scale batch reactor. The effects of solution $\mathrm{pH}$ (3-11), reaction time, pumice dosage (10, 15 and $20 \mathrm{~g} / \mathrm{L}$ ) and COD removal were evaluated. Natural mineral raw pumice and pumice-nZVI was used directly in nanocatalytic ozonation of dye of RB5 solution. Compared with raw pumice, pumice-nZVI into the ozonation reactor greatly accelerated the rate of RB5 degradation. The results indicate that with increasing $(\mathrm{pH}$, and pumice dosage) increased rate RB5 degradation. Molecular ozone direct oxidation mechanism was proved in nanocatalytic ozonation with pumice, and hydroxyl radical mechanism was demonstrated to play a main role in nanocatalytic ozonation with nZVI.

Keywords: Zonation, pumice, RB5, degradation, nanoscale zero valent iron (nZVI).

\section{Introduction}

Organic dyes are among the most important groups of wastewater contaminant, introduced into it through various industries including textile industry (Li et al., 2004; Aguedach et al., 2005). Today, around 100,000 types of dye(Ehrampoosh et al., 2011), with over $7 \times 10^{5}$ tons are produced for different uses including in textile, paper and leather production (Robinson et al., 2001; Pearce et al., 2003; Mahmoodi et al., 2006). Over 280,000 tons of the total global production of dyes annually enters directly into a wastewater (Maas and Chaudhari, 2005; Somasiri et al., 2008; Rahmani et al., 2010). Among the dyes, reactive dyes have more applications because of bright dyes, excellent dyefastness and ease of application (Elwakeel, 2009). Various physical, chemical and biological processes have been studied in the removal of dyes from wastewater (Hassaan et al., 2020; Khashij et al., 2020; Munagapati et al., 2020; Parsaeian et al., 2020). Advanced oxidation processes (AOPs) are alternative methods for the elimination of types of refractory compounds, principally due to the formation of hydroxyl radicals $(\mathrm{HO} \bullet)$. During advanced oxidation processes (AOPs), additional reactions occur in the presence of light that produce hydroxyl radicals or increase the production rate of hydroxyl radicals that are capable of rapidly oxidizing organic contaminants and converting them into harmless end-products, such as $\mathrm{H}_{2} \mathrm{O}$ and $\mathrm{CO}_{2}$, and inorganic ions from atoms, which have been successfully used for the treatment of wastewaters from petrochemical, textile, and pharmaceutical industries(Dimoglo et al., 2004; Tekin et al., 2006; Chakinala et al., 2009; Nachiappan and Muthukumar, 2010; Oller et al., 2011; Farzadkia et al., 2014; Wang et al., 2014; Gholami et al., 2016). Previous studies have documented the removal/degradation of benzotriazole with advanced techniques in recent years (e.g., ferrate (VI) oxidation, ultrasonic, adsorption, photochemical degradation)(Hem 
et al., 2003; Xu et al., 2010; Zúñiga-Benítez et al., 2014; Bahnmueller et al., 2015; Yazdanbakhsh et al., 2016).

Pumice is a volcanic rock that has a porous structure and large surface area (Yavuz et al., 2008). The pumice crystal structure creates open channels that make it easy for water and ions to pass through (Catalfamo et al., 2006). The easy processability of pumice as well as its use as a suitable and cost-effective adsorbent is as an interest (Moraci and Calabrò, 2010).

Nanocatalytic ozonation is a promising technology for the effective removal of water and wastewater contaminants that are refractory to conventional oxidation treatments. The main advantages of the catalytic processes with respect to traditional non-catalytic ozonation are better ozone utilization, increased contaminant removal efficiency and greater degree of organic matter mineralization(Legube and Leitner, 1999).

Among the various types of nanoparticles, Nanoscale zerovalent iron (nZVI) with small size, large surface area and high reactivity, is a good choice for use in processes to remove contaminants in water and wastewater (Fazlzadeh et al., 2016). The use of pumice, bentonite and zeolites along with iron nanoparticles increases its dispersibility (Liu et al., 2015).

The Nanocatalytic ozonation is an advanced oxidation process (AOP) that underlines generation of highly reactive hydroxyl radicals $\left({ }^{\circ} \mathrm{OH}\right)$ from a mixture of $\mathrm{Fe}^{2+}$ (ferrous ions) and $\mathrm{O}_{3}$. In Nanocatalytic ozonation (based using nano zero valent iron) and process ( $\left.\mathrm{nZVI} / \mathrm{O}_{3}\right)$, ferrous and then ferric are formed. During a regular cycle, these ions increase the efficiency of the process(Weng et al., 2013; Yazdanbakhsh et al., 2016).

This study presents experimental results on RB5 degradation by Nanocatalytic ozonation using raw and modified pumice. This is a natural mineral catalyst; Pumice has supplied an economical and feasible choice for nanocatalytic ozonation of RB5 in water.

\section{Materials and methods}

\subsection{Materials}

Chemicals used in the synthesis of nZVI, pumice, chloridric acid, sodium hydroxide, RB5 dye, ferric sulfate ( $\mathrm{Fe} 2$ (So4) 3 ), sodium borohydrate ( $\mathrm{NaBH} 4)$, ethanol, and starch were prepared from CMC (Germany). All laboratory preparations of the study were carried out according to the regulations set in the Standard Methods. Spectrophotometer was read using a method based on the determination of the absorption of each of these concentrations of Reactive Black 5 dye in the optimum wavelength $(599 \mathrm{~nm})$ (Figure 1 ).

All other chemicals required in the experiments were analytical grade reagents that were used without further purification (Merck). A stock solution of RB5 (1 g/L) was prepared in distilled water and in this study, a concentration of $50 \mathrm{mg} / \mathrm{L}$ was used for the experiments. Ozone was generated from pure oxygen by an ARDA ozone generator (Model AEGCOG-5S), and was fed continuously to the ozonation reactor at $0.61 \mathrm{mg} / \mathrm{L} \mathrm{min}$. The mass of ozone produced was measured by iodometric titration methods. The aqueous ozone concentration was determined by spectrophotometry using the indigo method (Clesceri et al., 1996). The COD was measured by Open reflex methods (Gholami et al., 2016).

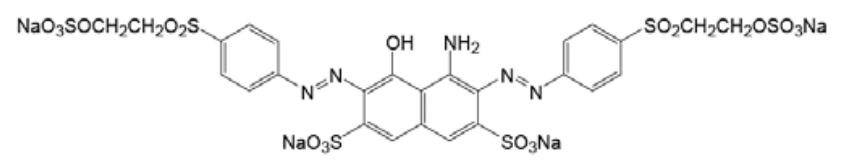

Figure 1. The chemical structure of the RB5

\subsection{Preparation and characterization of catalyst}

The pumice used in this investigation was a natural pumice that was obtained from the Miane region (North West of Iran). Chemical composition of the pumice determined by an Oxford (ED2000) XRF equipments. The surface morphology and shape of samples were taken by a scanning electron microscope (SEM) system (model: XL-30, Philips). Pumice-supported nanoscale zero-valent iron was prepared using conventional liquid-phase methods via the reduction of ferric ion $\left(\mathrm{Fe}_{2}\left(\mathrm{SO}_{4}\right)_{3} .6 \mathrm{H}_{2} \mathrm{O}\right)$ by borohydride $\left(\mathrm{NaBH}_{4}\right)$ and pumice was used as a support material(Shi et al., 2011). For preparation of surface-tailored pumice with $\mathrm{Fe}_{2}\left(\mathrm{SO}_{4}\right)_{3}, 50 \mathrm{~g}$ pumice was added into a $1000 \mathrm{ml}$ of 0.075 $\mathrm{M}$ ferric sulfate solution. The mixtures were intermittently agitated with a shaker at 200 RPM. After $48 \mathrm{~h}$ the pumices were washed several times using demineralized water to decrease the electrical conductivity. Finally, the modified pumice was dried in the ambient air for $48 \mathrm{~h}$ (Ahmadi et al., 2017). After converting the pumice to its cationic form with a Sodium Chloride solution and adding the cationic pumice into the metal salt solution, the $\mathrm{Na}^{+}$bound in the structure of the pumice was exchanged with $\mathrm{Fe}^{3+}$ from aqueous solution Eq. 1:

$$
\begin{aligned}
& \mathrm{Fe}^{3+} \text { (solution) }+3 \mathrm{Na}^{+} \text {(pumice) } \rightarrow \mathrm{Fe}^{3+} \text { (pumice) }+ \\
& 3 \mathrm{Na}^{+} \text {(solution) }
\end{aligned}
$$

$1 \mathrm{~g}$ of the pumice with $30 \mathrm{~mL}$ of $\mathrm{Fe} 2(\mathrm{SO} 4) 3$ solution (1M) in the presence of nitrogen gas were mixed for 3 hours. Then this solution was diluted in 5 -fold with ethanol and water solution (1: 1). In the next step, $100 \mathrm{~mL}$ of $\mathrm{NaBH} 4$ was added to this mixture in the $25{ }^{\circ} \mathrm{C}$ and placed on the magnetic stirrer for 30 minutes. After this time period, according to the Eq. 2 pumice was coated. The nZVI was separated and then washed three times with acetone at 65 ${ }^{\circ} \mathrm{C}$ using injecting nitrogen gas stored in a desiccator(Ahmadi et al., 2017). The synthesized materials were separated from the liquid solution via the magnet and dried at $65^{\circ} \mathrm{C}$ overnight.

$$
2 \mathrm{Fe}^{2+}+\mathrm{BH}_{4}^{-}+2 \mathrm{H}_{2} \mathrm{O} \rightarrow 2 \mathrm{Fe}^{0}+\mathrm{Bo}_{2}{ }_{2}+2 \mathrm{H}_{2}+4 \mathrm{H}^{+}
$$

For determining $\mathrm{pH}_{\mathrm{zpc}}$ pumice raw and modified, the 0.01 molar solution of Sodium Chloride as an electrolyte and Sodium hydroxide and Hydrochloric Acid with the purity of 0.1 molars were used as a controlling factor of $\mathrm{pH}$. Pore 30 $\mathrm{ml}$ of the electrolyte solution in 6 erlene of $50 \mathrm{ml}$ and adjusts its $\mathrm{pH}$ to a range of 2 to 12 using acids and alkaline. Then add $0.5 \mathrm{~g}$ pumice to each airline. Erlene was put on the shakers in a speed of 120 rounds per minute for $48 \mathrm{~h}$ 
and their final $\mathrm{pH}$ level was read using $\mathrm{pH}$-meter after infiltration. The $\mathrm{pH}_{\mathrm{ZPC}}$ point of pumice was determined using the graph of the primary levels of $\mathrm{pH}$. In this graph, drawing a line with a 45-degrees angle with the graph, those points with the same primary and final values of $\mathrm{pH}$ were taken as the $\mathrm{pH}_{\mathrm{zPC}}$ (Dastgheib et al., 2004).

Table 1. XRF results of chemical compositions for pumice

\begin{tabular}{llllllllllll}
\hline LOI & $\mathrm{Na}_{2} \mathrm{O}$ & $\mathrm{MgO}$ & $\mathrm{Al}_{2} \mathrm{O}_{3}$ & $\mathrm{SiO}_{2}$ & $\mathrm{P}_{2} \mathrm{O}_{5}$ & $\mathrm{SO}_{3}$ & $\mathrm{~K}_{2} \mathrm{O}$ & $\mathrm{CaO}$ & $\mathrm{TiO}_{2}$ & $\mathrm{Fe}_{2} \mathrm{O}_{3}$ & $\mathrm{Total}$ \\
\hline 8.01 & 1.87 & 0.866 & 14.5 & 66.219 & 0.14 & 0.037 & 2.7 & 2.5 & 0.42 & 2.61 & 99.952 \\
\hline
\end{tabular}
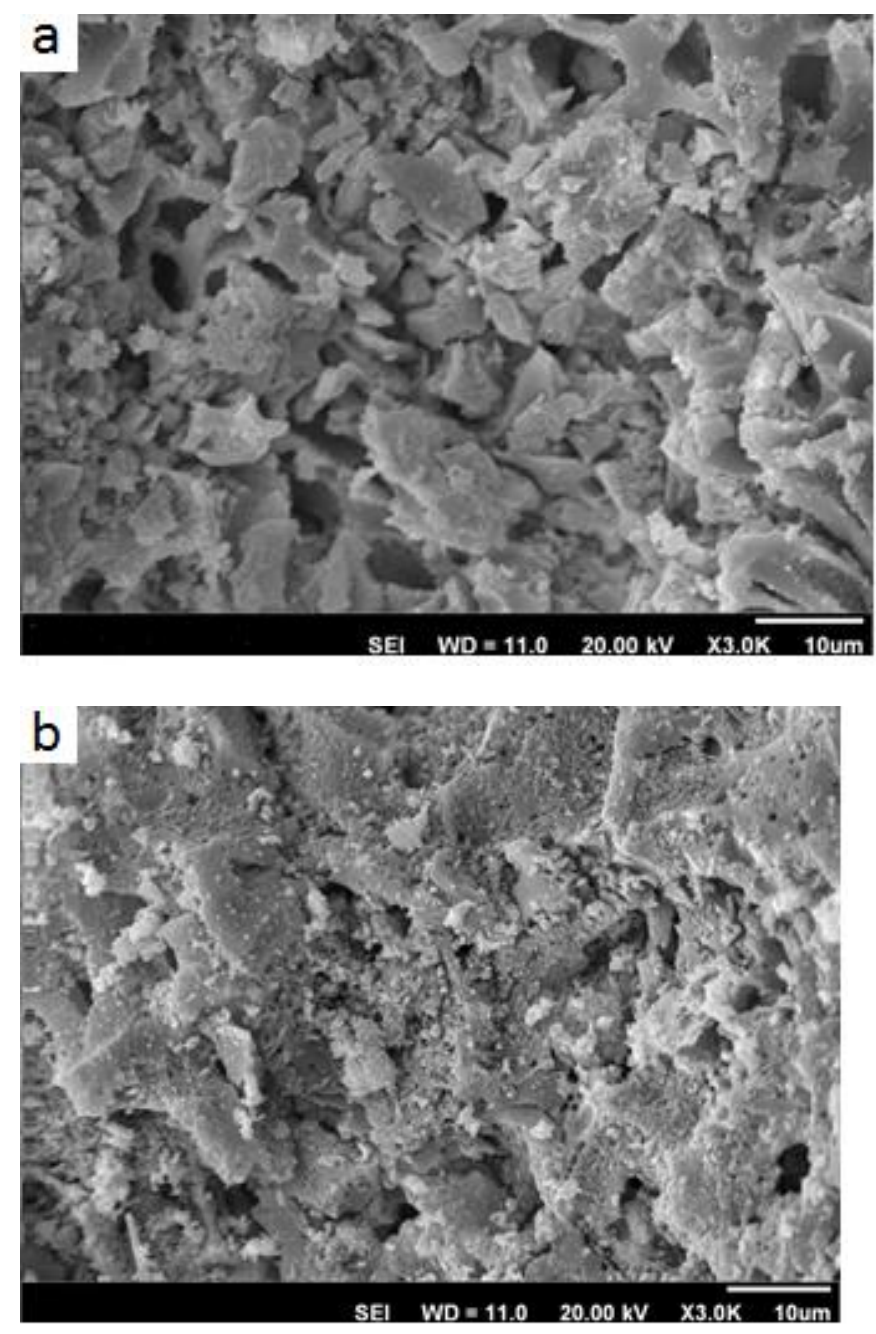

Figure 2. SEM of raw pumice (a) and pumice-nZVI (b)

\section{Results and discussion}

\subsection{Structural Analysis}

The crystal structure of the pumice, $X$ - ray fluorescence method (XRF) was used. The obtained results from chemical analysis of the sample are shown in Table 1 . The results of the structural characterization tests showed that this mineral sample was mostly composed of pumice (over $65 \%$ ) and some impurities such as clays, feldspar and quartz. The SEM image of the raw pumice and pumice modified with nanoscale zero valent iron ( $\mathrm{nZVI}$ ) sample is illustrated in Figure 2.

\subsection{Effect of the solution $\mathrm{pH}$}

The results of the impact of $\mathrm{pH}(3-11)$ on the ozonation processes with raw pumice and pumice-nZVI have been given in Figure 3. To determine the effect of $\mathrm{pH}$, specify the optimal $\mathrm{pH}$, and understand the effect of RHS in removal efficiency, in this study RB5 dye solution with a concentration of $50 \mathrm{mg} / \mathrm{L}$ was prepared and the removal efficiency was investigated. As seen in the figure, in the process of ozonation, with minutes of ozonation. The results of this step indicate that in the process of nanocatalytic ozonation using raw pumice, with a rise in $\mathrm{pH}$, the performance rate of RB5 degradation has increased from 37.1 percent to 82 percent ( $\mathrm{pH} 2$ to $\mathrm{pH} 9$ ). On the other hand, in the process of nanocatalytic ozonation using modified pumice after 60 minutes of ozonation, the performance rate of RB5 degradation has increased from 51.2 percent to 99.8 percent $(\mathrm{pH} \quad 2$ to $\mathrm{pH}$ 9). As results indicate, in all $\mathrm{pHs}$, the process of nanocatalytic ozonation has performed better compared to conventional processes of ozonation and with a rise in $\mathrm{pH}$, the process of dye degradation increase.

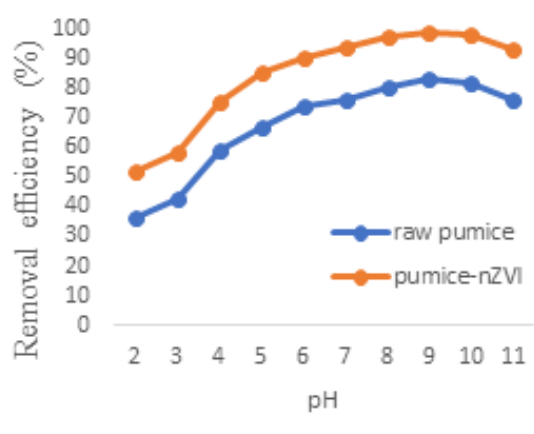

Figure 3. Effect of pH on removal efficiency of RB5 for ozonation raw pumice and pumice-nZVI

On the other hand, it was qualified to the dye structure as well as pumice structure and its $\mathrm{pH}_{\mathrm{zpc}}$. As noted, before, pHzPC of unprocessed and that of modified pumice will equal 7.3 and 7.11 respectively. Analyses indicate that in $\mathrm{pHs}$ upper than $\mathrm{pH}_{\mathrm{zPc}}$, active groups decay in the pumice surface and thus increase in the nucleophiliac character of these groups. Under this condition, the organic groups decomposed in the pumice surface increase the quickness of ozone reaction. Electron donning in these acidic acting groups transfers electrons to ozone and increase the progress in the speed of reaction and radicalization of ozone in the pumice surface. Finally, this electron transferring makes ozonized anions and contributes to radical cycle (Valdés et al., 2009). On the other hand, increase in $\mathrm{pH}$ triggers an increase in $\mathrm{OH}^{-}$ions. This ion is 
among the factors, which with an increase in $\mathrm{pH}$; act as initiators of the ozone decomposition reaction and precipitating the decomposition process. Chain reactions occurring in the ozone decomposition processes have been suggested as follows (Kasprzyk-Hordern et al., 2003). However, with the reduction of $\mathrm{pH}$ of the solutionthe number of sites with positive charge on the surface of nanoparticles and the adsorbent surface increases and an electrostatic attraction develops between the site with a positive charge on the surface of nanoparticles and the adsorbent and the molecules of reactive red 198 dye with a negative charge. With further absorption of dye molecules, nanocatalytic removal in turn increases (Alijani et al., 2013). Some works of literature attribute the dye degradation in the acidic conditions of the active nonhydroxyl radical in the catalyzer surface (Mortazavi et al., 2010). It seems that as the $\mathrm{pH}$ increases(9 to 11) the removal efficiency is reduced, that due to ionization of functional groups such as hydroxyl that it can reduce the amount of hydrogen radicals, negative charge is developed across the surface of nanoparticles whereby an electrostatic repulsion is developed between the surface of the nanoparticles with negative charge and the molecules of RB5 dye with a negative charge (Ahmadi et al., 2017).

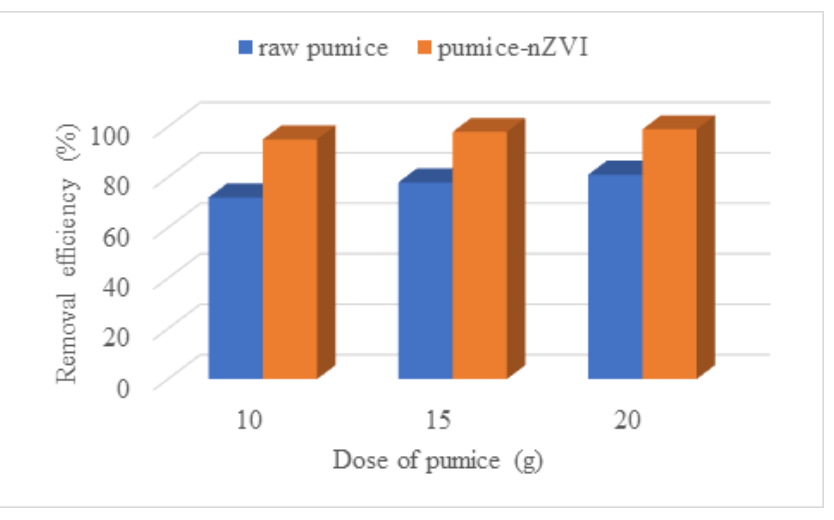

Figure 4. effect of dose of the materials on removal efficiency RB5 for ozonation raw pumice and pumice-nZVI

\subsection{The effect of dose of the materials}

One of the most important issues that should be taken into consideration in studying removal using catalysts is determining the suitable dose, which was another parameter that was investigated. Figure 4 indicates the effect of the initial dose of the materials on the removal efficiency of RB5 dye under $\mathrm{pH}=8$, contact time of $60 \mathrm{~min}$ with dye's initial concentration of $50 \mathrm{mg} / \mathrm{L}$. As indicated in the figure, in the contact time of 60 minutes with an increase in the catalyzer dose from 10 to $20 \mathrm{~g}$, the performance rate of RB5 dye degradation will increase. For example, with RB5 dye, an increase from 10 to $20 \mathrm{~g}$ of raw pumice, the performance rate of degradation increased from 68 percent to 76 percent. Also, with an increase in processed pumice-nZVI dose from 10 to $20 \mathrm{~g}$, the performance rate of RB5 degradation increased from 94 percent to 98.

This increase in dye decomposition in the nanocatalytic ozonation process has occurred as the result of an increase in the ozone decomposition in the pumice surface, which adds to the concentration of the radicals in the surface and in the liquid volume. Adding the catalyzer dose will increase the surface area and active sites of ozone absorption in the surface. Increased contact area between the deposited adsorbent and the contaminant, enumeration of active sites, and production of free electrons in the conductive band are among the reasons of elevation of removal efficiency with the increase in the dose of the materials(Samarghandi et al., 2011). In this regard, Ghaneian et al along with Samarghandi et al have reported an increase in the removal efficiency with the growth of a dose of the materials (Samarghandi et al., 2011). This increase also adds to the surface reactions and radical production in the nanocatalytic ozonation process. Many writers have reported the increase in performance rate of ozonation using catalysis with metal bases (Valdés et al., 2009). On the other hand, In catalyst coating nZVI behavior of ferrous ion is more important at low ferrous ion concentration and becomes less important as the concentration of ferrous ion increases with a ratio to oxidant concentration, because not all ferrous ions can be converted into ferryl ions and adequate ferrous ions will be available for the activation of oxidants at high ferrous ion concentration The effect of initial nZVI concentration is also important for the performance of the system. (Ahmadi et al., 2017).

\subsection{Effect of the nanocatalytic ozonation on the degradation of $C O D$}

Results show the amount of the COD degradation of RB5 in nanocatalytic ozonation with pumice-nZVI and raw pumice are that 81 and 54 percent, respectively. As indicated by the results in Figure 5, nanocatalytic ozonation with modified pumice-nZVI will decompose the dye further and will make it more mineralized, whereas ozonation with raw pumice will have less effect on COD degradation.

According to the results, it can be said that the effect of the presence of nano catalyst with ozonation results in a more complete analysis of the organic components than the method raw pumice. As COD is an indicator of decomposition of organic components, the catalytic ozonation will act to complete decomposition of a larger part of the dye than partial decomposition, while common oxidizers such as ozone will act to partial decomposition and in some cases, to add COD. The mechanism through which the $\mathrm{O}_{3} / \mathrm{nZVI}$ system produces oxidants involves the two-electron oxidation of nZVI followed by the Fenton-like reaction. Initially, nano zero valent iron is oxidized through a two-electron transfer from the particle surface to $\mathrm{O}_{3}$ (Khataee et al., 2010). Qu and Zheng examined the heterogeneous nanocatalytic ozonation with active carbon chains in phenol degradation from the wastewater. They reported that use of a level of $2 \mathrm{~g}$ active carbon chains solved in $250 \mathrm{ml}$ of water containing $100 \mathrm{mg}$. phenols, the nanocatalytic process can delete 99 percent of phenol content and 95 percent of chemical oxygen demand (COD) in the course of 30 minutes(Qu et al., 2007). 


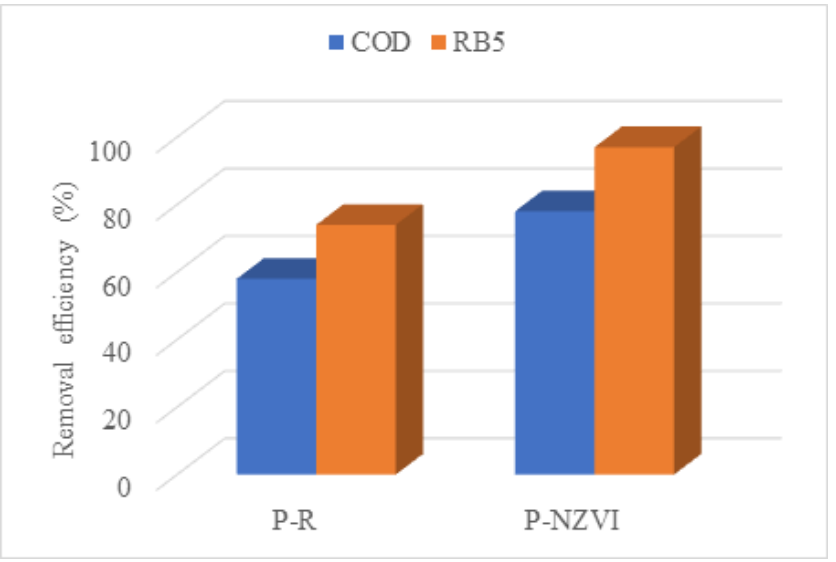

Figure 5. Removal efficiency of COD and RB5 by ozonation with raw pumice and pumice-nZVI

\section{Conclusions}

The results indicate that with increasing $(\mathrm{pH}$, and pumice dosage) increased rate RB5 degradation. Molecular ozone direct oxidation mechanism was proved in nanocatalytic ozonation with pumice, and hydroxyl radical mechanism was demonstrated to play a main role in nanocatalytic ozonation with $\mathrm{nZVI}$. As a natural mineral catalyst, pumice has supplied an economical and feasible choice for catalytic ozonation of RB5 in industrial wastewater.

\section{References}

Aguedach A., Brosillon S., Morvan J. and Lhadi E.K. (2005), Photocatalytic degradation of azo-dyes reactive black 5 and reactive yellow 145 in water over a newly deposited titanium dioxide, Applied Catalysis B: Environmental, 57(1), 55-62.

Ahmadi M., Rahmani K., Rahmani A. and Rahmani H. (2017), Removal of benzotriazole by Photo-Fenton like process using nano zero-valent iron: response surface methodology with a Box-Behnken design, Polish Journal of Chemical Technology, 19(1), 104-112.

Alijani S., Vaez M. and Zaringhalam Moghadam A. (2013), Comparative study on the photodegradation of Acid Black 26 from synthetic wastewater using slurry and immobilized $\mathrm{TiO}_{2}$ on the sackcloth fiber, Iranian Journal of Health and Environment, 6(2), 243-256.

Bahnmueller S., Loi C.H., Linge K.L., Von Gunten U. and Canonica S. (2015), Degradation rates of benzotriazoles and benzothiazoles under UV-C irradiation and the advanced oxidation process UV/ $\mathrm{H}_{2} \mathrm{O}_{2}$. Water Research, 74, 143-154.

Catalfamo P., Arrigo I., Primerano P. and Corigliano F. (2006), Efficiency of a zeolitized pumice waste as a low-cost heavy metals adsorbent, Journal of Hazardous Materials, 134(1-3), 140-143.

Chakinala A.G., Gogate P.R., Burgess A.E. and Bremner D.H. (2009), Industrial wastewater treatment using hydrodynamic cavitation and heterogeneous advanced Fenton processing, Chemical Engineering Journal, 152(2), 498-502.

Clesceri L.S., Greenberg A.E. and Trussell R. (1996). Standard methods for the examination of water and wastewater, APHA, AWWA and WPCF, Washington DC.

Dastgheib S.A., Karanfil T. and Cheng W. (2004), Tailoring activated carbons for enhanced removal of natural organic matter from natural waters, Carbon, 42(3), 547-557.
Dimoglo A., Akbulut H., Cihan F. and Karpuzcu M. (2004), Petrochemical wastewater treatment by means of clean electrochemical technologies, Clean Technologies and Environmental Policy, 6(4), 288-295.

Ehrampoosh M., Moussavi G., Ghaneian M., Rahimi S. and Ahmadian M. (2011), Removal of methylene blue dye from textile simulated sample using tubular reactor and $\mathrm{TiO}_{2} / \mathrm{UV}-\mathrm{C}$ photocatalytic process, Journal of Environmental Health Science \& Engineering, 8(1), 34-40.

Elwakeel K.Z. (2009), Removal of Reactive Black 5 from aqueous solutions using magnetic chitosan resins, Journal of Hazardous Materials, 167(1-3), 383-392.

Farzadkia M., Rahmani K., Gholami M., Esrafili A., Rahmani A. and Rahmani H. (2014). Investigation of photocatalytic degradation of clindamycin antibiotic by using nano-ZnO catalysts, Korean Journal of Chemical Engineering, 31(11).

Fazlzadeh M., Rahmani A., Nasehinia H.R., Rahmani H. and Rahmani K. (2016), Degradation of sulfathiazole antibiotics in aqueous solutions by using zero valent iron nanoparticles and hydrogen peroxide, Koomesh, 350-356.

Gholami M., Rahmani K., Rahmani A., Rahmani H. and Esrafili A. (2016), Oxidative degradation of clindamycin in aqueous solution using nanoscale zero-valent iron $/ \mathrm{H}_{2} \mathrm{O}_{2} / \mathrm{US}$, Desalination and Water Treatment, 57(30), 13878-13886.

Hassaan M., El Katory M., Ali R.M. and El Nemr A. (2020), Photocatalytic degradation of reactive black 5 using PhotoFenton and $\mathrm{ZnO}$ nanoparticles under UV irradiation, Egyptian Journal of Chemistry, 63(4), 17-18.

Hem L.J., Hartnik T., Roseth R. and Breedveld G.D. (2003), Photochemical degradation of benzotriazole, Journal of Environmental Science and Health, Part A, 38(3), 471-481.

Kasprzyk-Hordern B., Ziółek M., and Nawrocki J. (2003), Catalytic ozonation and methods of enhancing molecular ozone reactions in water treatment, Applied Catalysis B: Environmental, 46(4), 639-669.

Khashij M., Dalvand A., Mehralian M., Ebrahimi A.A. and Khosravi R. (2020), Removal of reactive black 5 dye using zero valent iron nanoparticles produced by a novel green synthesis method, Pigment \& Resin Technology.

Khataee A.R., Zarei M. and Moradkhannejhad L. (2010), Application of response surface methodology for optimization of azo dye removal by oxalate catalyzed photoelectro-Fenton process using carbon nanotube-PTFE cathode, Desalination, 258(1), 112-119.

Legube B. and Leitner N.K.V. (1999). Catalytic ozonation: a promising advanced oxidation technology for water treatment, Catalysis Today, 53(1), 61-72.

Li J., Xu Y., Liu Y., Wu D. and Sun Y. (2004), Synthesis of hydrophilic ZnS nanocrystals and their application in photocatalytic degradation of dye pollutants, China Particuology, 2(6), 266269.

Liu T., Wang Z.-L. and Sun Y. (2015), Manipulating the morphology of nanoscale zero-valent iron on pumice for removal of heavy metals from wastewater, Chemical Engineering Journal, 263, 55-61.

Maas R. and Chaudhari S. (2005). Adsorption and biological decolourization of azo dye Reactive Red 2 in semicontinuous anaerobic reactors, Process Biochemistry, 40(2), 699-705.

Mahmoodi N.M., Arami M. and Limaee N.Y. (2006). Photocatalytic degradation of triazinic ring-containing azo dye (Reactive Red 
198) by using immobilized $\mathrm{TiO}_{2}$ photoreactor: bench scale study, Journal of Hazardous Materials, 133(1), 113-118.

Moraci N. and Calabrò P.S. (2010), Heavy metals removal and hydraulic performance in zero-valent iron/pumice permeable reactive barriers, Journal of Environmental Management, 91(11), 2336-2341.

Mortazavi S., Asgari G., Hashemian S. and Moussavi G. (2010), Degradation of humic acids through heterogeneous catalytic ozonation with bone charcoal, Reaction Kinetics, Mechanisms and Catalysis, 100(2), 471-485.

Munagapati V.S., Wen J.-C., Pan C.-L., Gutha Y., Wen J.-H. and Reddy G.M. (2020), Adsorptive removal of anionic dye (Reactive Black 5) from aqueous solution using chemically modified banana peel powder: kinetic, isotherm, thermodynamic, and reusability studies, International Journal of Phytoremediation, 22(3), 267-278.

Nachiappan S. and Muthukumar K. (2010), Intensification of textile effluent chemical oxygen demand reduction by innovative hybrid methods, Chemical Engineering Journal, 163(3), 344-354.

Oller I., Malato S. and Sánchez-Pérez J. (2011), Combination of advanced oxidation processes and biological treatments for wastewater decontamination-a review, Science of the Total Environment, 409(20), 4141-4166.

Parsaeian M.R., Dadfarnia S., Haji Shabani A.M. and Hafezi Moghaddam R. (2020), Green synthesis of a high capacity magnetic polymer nanocomposite sorbent based on the natural products for removal of Reactive Black 5, International Journal of Environmental Analytical Chemistry, 1-15.

Pearce C., Lloyd J. and Guthrie J. (2003), The removal of colour from textile wastewater using whole bacterial cells: a review, Dyes and Pigments, 58(3), 179-196.

Qu X., Zheng J. and Zhang Y. (2007), Catalytic ozonation of phenolic wastewater with activated carbon fiber in a fluid bed reactor, Journal of Colloid and Interface Science, 309(2), 429434.

Rahmani A., Nouri J., Kamal Ghadiri S., Mahvi A. and Zare M.R. (2010), Adsorption of fluoride from water by $\mathrm{Al} 3+$ and $\mathrm{Fe} 3+$ pretreated natural Iranian zeolites, International Journal of Environmental Research, 4(4), 607-614.

Robinson T., McMullan G., Marchant R. and Nigam P. (2001), Remediation of dyes in textile effluent: a critical review on current treatment technologies with a proposed alternative, Bioresource Technology, 77(3), 247-255.

Samarghandi M., Siboni M., Maleki A., Jafari S.J. and Nazemi F. (2011), Kinetic determination and efficiency of titanium dioxide photocatalytic process in Removal of Reactive Black 5 (RB5) dye and cyanide from aquatic solution, Journal of Mazandaran University of Medical Sciences, 21(81), 44-52.

Shi L.-n., Zhang X. and Chen Z.-I. (2011). Removal of chromium (VI) from wastewater using bentonite-supported nanoscale zerovalent iron, Water Research, 45(2), 886-892.

Somasiri W., Li X.-F., Ruan W.-Q. and Jian C. (2008), Evaluation of the efficacy of upflow anaerobic sludge blanket reactor in removal of colour and reduction of $C O D$ in real textile wastewater, Bioresource Technology, 99(9), 3692-3699.

Tekin H., Bilkay O., Ataberk S.S., Balta T.H., Ceribasi I.H., Sanin F.D., Dilek F.B. and Yetis U. (2006). Use of Fenton oxidation to improve the biodegradability of a pharmaceutical wastewater, Journal of Hazardous Materials, 136(2), 258265.
Valdés H., Farfán V.J., Manoli J.A. and Zaror C.A. (2009), Catalytic ozone aqueous decomposition promoted by natural zeolite and volcanic sand, Journal of Hazardous Materials, 165(1), 915-922.

Wang Y., Chen K., Mo L., Li J. and Xu J. (2014), Optimization of coagulation-flocculation process for papermakingreconstituted tobacco slice wastewater treatment using response surface methodology, Journal of Industrial and Engineering Chemistry, 20(2), 391-396.

Weng C.-H., Lin Y.-T., Chang C.-K. and Liu N. (2013), Decolourization of direct blue 15 by Fenton/ultrasonic process using a zero-valent iron aggregate catalyst, Ultrasonics Sonochemistry, 20(3), 970-977.

Xu B., Wu F., Zhao X. and Liao H. (2010). Benzotriazole removal from water by $\mathrm{Zn}-\mathrm{Al}-\mathrm{O}$ binary metal oxide adsorbent: Behavior, kinetics and mechanism, Journal of Hazardous Materials, 184(1), 147-155.

Yavuz M., Gode F., Pehlivan E., Ozmert S. and Sharma Y.C. (2008). An economic removal of $\mathrm{Cu}^{2+}$ and $\mathrm{Cr}^{3+}$ on the new adsorbents: Pumice and polyacrylonitrile/pumice composite, Chemical Engineering Journal 137(3), 453-461.

Yazdanbakhsh A., Rahmani A., Massoudinejad M., Jafari M. and Dashtdar M. (2016), Accelerating the solar disinfection process of water using modified compound parabolic concentrators (CPCS) mirror. Desalination and Water Treatment, 57(50), 23719-23727.

Zúñiga-Benítez H., Soltan J. and Peñuela G. (2014), Ultrasonic degradation of 1-H-benzotriazole in water, Water Science and Technology, 70(1), 152-159. 